\title{
On the Threshold: Haunting Transgressions in Gaétan Soucy's The Little Girl Who Was Too Fond of Matches
}

\author{
Zuzanna Szatanik \\ University of Silesia in Katowice \\ zuzanna.szatanik@us.edu.pl
}

Received 6 March 2017; accepted 18 October 2017.

\begin{abstract}
The main aim of this article is to show how Gaétan Soucy's 1998 bestselling novel The Little Girl Who Was Too Fond of Matches both extends and complicates the Canadian Gothic tradition. The first part focuses on Canada as a "haunted culture," and attempts to identify the ghosts which haunt Canada and make themselves manifest in the nation's gothic literature. I ponder the postcolonial character of Canadian Gothic, and reflect on the representations of monstrous nature in Canada's early fiction. A short section is devoted to the characteristics of French-Canadian Gothic. The second part of my article proposes a reading of Soucy's novel which concentrates on gothic transgressions the story revolves around. One of my assumptions is that the novel invites ecocritical and ecofeminist interpretations, and that its representations of nature also reveal the subversive character of the text whose narrator, by her own admission, locates herself on the threshold of things.
\end{abstract}

Keywords: Canadian literature; Quebec literature; Canadian Gothic; Gaétan Soucy; transgression.

The main goal of my article is to show how Gaétan Soucy's 1998 The Little Girl Who Was Too Fond of Matches both extends and complicates the Canadian Gothic tradition. Originally published in French, Soucy's novel has since been translated into more than twenty languages, and has become one of the most recognizable French-Canadian literary works. Its author, in a way reminiscent of Edgar Allan Poe, has been described as "a strange and difficult man" who "battled demons." His untimely death in 2013, more than a decade after he published his last novel Vaudeville!, only added more gloom to his already dismal 
image. The Little Girl, similarly, has attained a near-mythical ambience, as it took Soucy less than a month to write. Allegedly, the story was created during an epic ice-storm which paralysed Quebec in January 1998, imprisoning thousands of people in their homes (Hustak, 2013). A mystifying read, the short novel is a little book of excess, a "grimoire" (Whelan, 2011, p. 178), whose labyrinthine structure is built on countless gothic tropes. Narrated by a character whose name is only revealed on the last pages of the story, and whose gender remains mysterious for a good part of it, The Little Girl revolves around the themes of crime, mystery, victimization, death, transgression and punishment. Whereas a reading of Soucy's novel remains the primary goal of this article, its introductory part is built on the assumption that Canada, like other nations, has been haunted, and aims to identify the specific order of ghosts haunting Canadian literature.

There are a number of quotations that have turned to be milestones in English-Canadian nation/narration which invoke ghosts, or rather the absence thereof. For example, in 1836 The Backwoods of Canada, Catharine Parr Traill "famously proclaimed that Canada was "too matter-of-fact a country for the supernatural"' (Sugars, 2009, p. xiii). In 1852, her sister Susanna Moodie insisted that the country "was too new for ghosts" (in Sugars, 2009, p. xiii). Over a century later, Canadian poet Earle Birney wrote in his poem entitled "CanLit" that "it's only by [their] lack of ghosts [that Canadians are] haunted" (in Sugars, 2009, p. xiii). Finally, a protagonist of Margaret Atwood's early novel Surfacing, "makes a comment that has become one of the most widely circulated citations in Canadian literature. 'Canada was built on dead beavers,' he says" (Berland, 2015, p. 25). Whereas the last quotation does not mention ghosts per se, it complements the other statements in that it seemingly de-gothicizes Canadianness. What it suggests is that there is pragmatism to Canadianness, and some irony too, which are not consonant with the gothic mode. Canadians, in Cynthia Sugars' words, "[inherit] a niggling sense that they [are] dull" (2009, p. 3).

Contrary to what these sober citations suggest, all of the four writers mentioned above repeatedly referred to Canadian nature as mystifying and threatening. To the $19^{\text {th }}$-century settler women, wilderness loomed both breathtaking and hostile. In Margaret Atwood's poetic retelling of Susanna Moodie's journals, as well as in Birney's poem entitled "Bushed," nature confounds, petrifies, and drives one insane. This is why, as Northrop Frye famously proclaimed, Canadians develop a garrison mentality to protect themselves from the adversities of nature (1973, p. 830). In fact, in her seminal 1972 study entitled Survival: A Thematic Guide to Canadian Literature Atwood affirms that "Nature the Monster" is one of the most prevalent themes in Canadian letters, as "there's lots of water and snow in Canada, and both are good murder weapons" (1972, p. 55). Deadly wilderness becomes, therefore, one of the most haunting presences in Canadian fiction. This form of haunting, in the words of Jennifer Andrews, "takes two forms: the literal fear of the untamed natural world encountered by new immigrants and the accompanying realization that such perceptions of emptiness depend upon often naive presumptions of what constitutes civility and order" (2009, p. 210). Forts, in truth, offer only illusory protection against the wilderness and often become sites of haunting transgressions. 
Whereas Atwood's early interest was in delineating Canadian national myths - the interest she shared with other thematic critics - present-day Canadian writers are invested in "deconstructing [these very] national myths that, created in the 1960s, have . . haunted literary and cultural production in Canada since" (Darias-Beautell, 2012, p. 4). In Marlene Goldman and Joanne Saul's terms, they are, in fact, "obsessed with ghosts and haunting" (as cited in Darias-Beautell, 2012, p. 7), and have been led, as another critic professes, "to conjure, and indeed channel, the crowded landscape of ghosts and monsters that circulate above, around, and within the parameters of the Canadian nationalist project" (Sugars, 2009, p. xiii). Arguably, Canadian literature still somehow "feeds upon" old myths, by way of "negotiating with the dead" and "bringing to the fore a sense of the forgotten and unacknowledged, the repressed and the denied" (Sugars, 2009, p. xiv). These gothic gestures are aimed against the apparent "'stupefying innocence' in Canadian nation-narration" (Kulperger, 2009, p. 101) as "[t]he Canadian discourse of the nation is haunted by the spectre of Aboriginal and diasporic others - a haunting that renders problematic the construction of a cohesive national identity" (Laouyene, 2009, p. 127).

The belief in the supposed innocence of Canada's past is reflected in the famous quotation about dead beavers I brought up earlier; "The beaver," continues Atwood's protagonist, "is to this country what the black man is to the United States" (Berland, 2015, p. 25). The present-day "preoccupation with haunting in Canadian writing" (Goldman, 2012, p. 5), conversely, helps to deconstruct the myth of Canada's colonial inculpability as it "seeks to, above all, materialize and familiarize [the] motifs of trauma . . grounding [it] in the brutal realities and ongoing legacies of colonization" (Kulperger, 2009, p. 98). In Marlene Goldman's words,

In a country like Canada, with four major waves of immigration after the initial period of British and French colonization, and a fifth wave that is currently ongoing - the tropes of (dis)possession and haunting may be a particularly useful way to think about the relationship between history and memory, about displacement, about ancestors, and about inheritance. (2012, p. 15)

It is then not the beaver that is the black man of Canada; it is the black man that is the black man of Canada where "slavery was practiced in a third of what" now constitutes the country (Goldman, 2012, p. 9). The Canadian writers who use "traditional gothic conventions" often do so in order "to expose the lingering remnants of the past within the presentday postcolonial nation” (Kulperger, 2009, p. 98).

Whereas the colonial legacy haunts the literatures of both English and French Canada, there are a number of symbols and metaphors which have been linked specifically to Quebec Gothicism. According to Atwood, the characters of English-Canadian literature are sentenced to "death by nature," while French-Canadian protagonists burn to death in their mansions (1972, chapter 11). English-Canadian gothic literature often expresses "guilt concerning [the] treatment of the indigenous peoples" and "the legacy of slavery" (Goldman, 2012, p. 9), whilst French-Canadian Gothic, as Michel Lord suggests, 
seems content to deny history or even to ignore that it happened. Historical reality, be it the fact that the Acadians were deported or the fact that New France did fall, is rejected in favor of a fictional "dream-state" whereby a lost past is imaginatively restored. (as cited in Cabajsky, 2009, p. 6)

This, in Lord's words, “is responsible for French-Canadian Gothic's conservative tenor" (as cited in Cabajsky, 2009, p. 6). Among the typical themes in French-Canadian gothic fiction, Cedric May mentions the theme of ancestral home, "harking back to the seigneurial origins of Quebec society," and "the tragic orphan theme" (May, 2002). Even though pointing out which of these motifs are present in Soucy's novel would be a rather uncomplicated task - as many of them were employed by the author of The Little Girl - the following interpretive part of my presentation focuses on gothic transgression, a classic gothic trademark, which makes Soucy's work a subversive rather than representative example of the French-Canadian tradition. As a gothic story, The Little Girl "both enacts and thematizes ambivalence" (Sugars, 2009, p. xv) and refuses to fully align itself "with [any] nationalist theology" (Cabajsky, 2009, p. 6). Accordingly, the frame-or a skeletonupon which the story is built is conspicuously inscribed within the classic gothic mode.

The Little Girl Who Was Too Fond of Matches, which is divided into two parts and "spans a time frame of [merely] two days" (Wiesenthal, 2014), tells the story of the Soissons family "whose [seemingly] arcadian existence [was] shattered" (Cabajsky, 2009, p. 3). The opening paragraphs of the novel are perplexing, as the events unfold abruptly and the language in which they are told is mystifying itself. The story begins with a suicidal death of the autocratic father of the family - the "papa" who "gave up the ghost without a by-yourleave" (Soucy, 2000, p. 3) - and the decisions his two children have to make on discovering his body. The setting is an old ruined mansion, a symbol of the family's past wealth and its present disintegration. In this Pandora box of a beginning, uncomfortable secrets of the family are hinted at, the first of which being that the father had kept his children imprisoned in the house, preventing them from virtually any contact with the outside world. The reader also learns about a mysterious creature named the Fair Punishment, kept in a box in a woodshed, aka "the vault" (p. 8), to which the narrator refers to as "quite something" which "will surprise the world one day" (p. 8). The vault is also a place where a puzzling glass box is stored, which the narrator promises to talk about later, "in the proper place at the proper time" (p. 8). Before ascertaining the "papa's" death, she suspects the man was simply having "a stopit" without explaining what it might indicate.

Some of these puzzles are only explained on the last pages of the novel - it is how the narrator's name, Alice, is revealed-some are never clarified. The stopit, for instance, which runs in the family, has been most often interpreted as an epileptic fit, but could as well indicate a panic attack. What we do learn, on the other hand, is that the Fair Punishment is the eponymous little girl who was too fond of matches, and the narrator's twin sister Ariane. At the age of three Ariane set the mansion on fire in which her mother died, and in which she was severely burned. In an act of "fair punishment," the father put his harmed child in a box to which she is now chained, and locked her in the "vault" together with the body of the mother-kept in the glass coffin — and a box of matches, a constant 
remainder of Ariane's sin for her to contemplate. In the background of these ghastly revelations, we also learn that the narrator has "hidden away to flee the disaster and to write [her] last will and testament" (Soucy, 2000, pp. 8-9) which is the text itself. The chronicler weaves her story hastily and in secret, which is why it seems disordered, and often proffers overlapping realities and temporalities.

The distinctly gothic character of Soucy's novel is evoked not only through the classic gothic tropes or crime, mystery, and danger but through the deliberately de-naturalized, transgressive language of the text. What the two children know about the world comes from their limited experience and, more importantly, from the biblical and philosophical texts, as well as tales of chivalry that their father - a former priest become a mine owner-fed them with. The language the narrator uses is therefore strangely archaic, and is "an oddly extravagant pastiche of stylized 'days of yore' (3), private euphemism, poetic neologism, inadvertent malapropism, comically blunt literalism, and snatches of contemporary slang" (Wiesenthal, 2014). It is also the language that represents the "perverse symbolic order" of the dead father (Wiesenthal, 2014), in which women are either "sluts" or "blessed virgins," breasts are referred to as "inflations," and male genitals become "attributions." In a disquietingly detached manner, the narrator uses this language to describe her father's corpse:

since father was dressed like eve, it was as if we were on first-name terms with his balls. They were all soft and chubby, much bigger than brother's, or mine in the days when I still had them, and they hung there on the stiff white body like a bearded baby's face. (Soucy, 2000, p. 18)

In a similarly dispassionate, estranged way she asserts having been repeatedly raped by her brother, and mentions her practice of "flicking [menstrual] blood" at him as a defensive gesture.

As the story develops, however, the narrator seems to appropriate her father's language and the text transforms from a daily exercise in noting down important events (which the family practiced) into an emotional private confession and a trauma narrative. The narrator's own story breaks through the complicated linguistic net fabricated by her father. Soucy's then is "a nightmarish subversion of the fairy-tale mode" (Wiesenthal, 2014), which details numerous rites of passage that culminate in the metamorphosis of the narrator, the rites whose outcomes, however, are never definitive. In the subsequent parts of this essay, for the sake of clarity and in respect of space limits, I focus on merely three different examples of gothic transgressions presented in The Little Girl. These concern the crossing of the borderlines between the inside and the outside, the subverting of the categories of gender, as well as the undermining of the distinction between human and animal.

The most literal transgression the narrator experiences is the overstepping of the boundaries of her father's domain marked by a pine grove "blocking the horizon" (Soucy, 2000, p. 7), and entering the village on the other side of it. The act of crossing over the boundaries of the estate is not only one of necessity - she feels obliged to buy a "grave box" to bury her father in - but also disobedience. As a violation of their father's strict rules, it frightens her brother much more than the prospect of staying in with the corpse. The liminal space 
of the road leading to the village is an uncharted territory which the narrator tests "with the toe of [her] boot before setting out along it for the first time in [her] life" (p. 27). She is surprised the earth does not yield and is "able to support [her] there too" (p. 27). The girl enters the unfamiliar realm armed with a spade "to defend [herself] against serpents or lions" (p. 29) and expects there to be "a palace with a drawbridge and flying carpets overhead" (p. 29). Instead, the landscape she intrudes is recognizably Catholic, with its center marked by a church in which a funeral service is being held.

Although the narrator "[knows] a thing or two about [churches as] ever since [she]' $d$ been old enough to remember being hit, father had taught [her] all the things in a church inside and out" (Soucy, 2000, p. 30), this public space proves to be as hostile as her father's. Misunderstood by the inhabitants of the village and threatened by the crowd in the square outside the church, the girl finds herself "in the grip of a stopit" (p. 43). "When I have a stopit," she explains, "time contracts or expands or goes in circles, it's impossible to know" (p. 43). In this surreal state, her body shuts down, but the girl remains "extremely active on the inside" (p. 43); "I look through my ruminant eyes," she intimates,

as I would look through a window with the eyes we have inside our bonnets, I observe everything in every direction so that nothing escapes me, I climb inside my body as if I were hiding in the attic and spying on the world through the bull's eye, ah la la, another eye. (p. 43)

A stopit thus is an extreme experience of derealization which transcends logic, in which the girl seems both dead and alive, animate and inanimate, in control and out of it. Even though the stopit is temporary, and the narrator's quest is unsuccessful (its consequences, in fact, prove to be disastrous for the Soissons siblings), what the girl learns through "stepping outside the enclosure of the estate" is that "once that boundary had been crossed [she] could pass through the others as easily..." (Soucy, 2000, p. 32). Freed from her father's regime and unfitted for the narrow structures of the village, the narrator positions herself on the threshold (p. 112), and wishes "to stay forever on the road through the pine grove" (p. 64), in-between the realm of the father and the realm of the priest. It is outside of her ancestral home, as well as outside of the village, in the transgressive "outside of" space, that the girl wishes to dwell.

The narrator's spatial dislocation harmonizes with her crossing over the boundaries of gender. Raised as one of her father's "thin, daydreamy sons" (Soucy, 2000, p. 13), in the first part of the novel she seems to accept the kind of identification that her father forced upon her. As she reveals,

Once upon a long time ago, a true calamity happened to me, I think I lost my balls. I bled for days and then it healed over and then it started up again, it depends on the moon, ah la la, it's because of the moon, and I started to get inflations on my torso as well. (p. 56)

As a castrated boy with "inflations," the narrator is conflicted as to her own gender identity, also for the reason that according to her father's teachings most women are sluts, and the blood she drips is "disgusting" (Soucy, 2000, p. 44). It is only at the end of the first part of the novel, after she narrates having had sex with a mine inspector-whom she 
refers to as a knight, a prince, and a handsome cavalier - that the narrator decides to "use the gender of sluts for [her] pronouns" although she still defines herself as "[her] father's son and [her] brother's brother" (p. 61).

Finally, in the second part of the book, a realization "[springs] to [the narrator's] mind like a tiger" that she "too [is] a soissons slut" (Soucy, 2000, p. 77). This is followed by a recognition that having been treated like a son by her father "put a rod between [her] legs, figuratively speaking" (p. 128), and a startling revelation that the process of writing her testimony-which she has been engaged in for two days - is mirrored by the process of giving birth to her child whom the narrator suspects to be a girl, and plans to name Ariane, in memory of Fair Punishment (p. 137). The narrator's body, therefore, becomes a site of a corporeal transgression.

Coming to terms with her markedly female body is depicted as a liberating experience through which Alice can now "move around freely within [herself]" (Soucy, 2000, p. 128). Undoubtedly, it also relegates her to the realm of nature which has stereotypically been associated with a woman. Regardless of its emancipatory qualities, however, the girl finds nature both mighty and confounding (p. 132). Accordingly, although the girl's testimony revolves around the seemingly clear contrast between culture and nature, the boundaries between the two are always transgressed. One of the most striking characteristics of the novel, for example, are the constant references to the animal world and - in line with the principal tenets of human-animal studies - the blurring of the distinction between human and animal. The girl's faithful companion is not her brother but a horse who "lacks only the power of speech, and even that depends on what you call speech" (p. 74). The Fair Punishment, chained to her box and speechless, is unmistakably animal-like. The narrator's half-witted brother looks "like an animal that's being beaten and doesn't understand why" (p. 5). The crowd outside the church transforms "into a long undulating animal, a kind of snake with feet and, for the snout, a coffin" (p. 37), and partridges panic because “it's only human" (p. 27).

In the second part of the novel Alice's narrative develops towards an environmental poetics and ecological imagination. "The beasts," she proposes, "are as immaculate as the palm of the clouds, which are innocent to the core" (Soucy, 2000, p. 135); "Beets are like us, and so are the rats that gnaw them" (p. 97). The narrator sleeps outside and eats only plants. At the sight of her father and brother eating partridges she experiences extreme revulsion: "I'd have vomited my insides out if anyone had obliged me to put pieces of boiled partridge corpse in my mouth, and I was crying inside as I watched them eat, though it didn't show" (p. 107). The family mansion is now overtaken by nature, with "rot and corruption lying ... everywhere" (p. 89), and the corpses of farm animals starved by her father decomposing all around the estate.

Arguably, Alice uses animal metaphors to express her intense vulnerability and to lay emphasis on the transitory, slippery nature of any role and position available to her. Accordingly, this open-ended narrative closes at "a moment of pure potentiality" when nothing is certain, the moment of "imminent birth and/or death" (Wiesenthal, 2014). Even though 
the novel abounds in other classic gothic motifs (such as mystery, crime, or ghostly murmurs in an abandoned ballroom), as well as recognizably French-Canadian gothic tropes (be it an ancestral home, a burning mansion or a tragic orphan), it is, I believe, gothic transgression which becomes the most haunting — and also the most Canadian — presence in Soucy's novel.

\section{References}

Andrews, J. (2009). Rethinking the Canadian Gothic: Reading Eden Robinson's Monkey Beach. In C. Sugars \& G. Turcotte (Eds.), Unsettled remains: Canadian literature and postcolonial Gothic (pp. 205-227). Waterloo, ON: Wilfrid Laurier University Press.

Atwood, M. (1972). Survival: A thematic guide to Canadian literature. Toronto, ON: Anansi.

Berland, J. (2015). The work of the beaver. In T. Allen \& J. Blair (Eds.), Material cultures in Canada (pp. 25-50). Waterloo, ON: Wilfrid Laurier University Press.

Cabajsky, A. (2009). Catholic Gothic: Atavism, orientalism, and generic change in Charles De Guise's Le Cap au diable. In C. Sugars \& G. Turcotte (Eds.), Unsettled remains: Canadian literature and postcolonial Gothic (pp. 1-21). Waterloo, ON: Wilfrid Laurier University Press.

Darias-Beautell, E. (2012). Introduction: Why Penelopes? How unruly? Which ghosts? Narratives of English Canada. In E. Darias-Beautell (Ed.), Unruly Penelopes and the ghosts: Narratives of English Canada (pp. 1-18). Waterloo, ON: Wilfrid Laurier University Press.

Frye, N. (1973). Conclusion. In C. F. Klinck (Ed.), Literary history of Canada: Canadian literature in English (pp. 821-849). Toronto, ON: University of Toronto Press.

Goldman, M. (2012). DisPossession: Haunting in Canadian fiction. Montreal, QC: McGill-Queen's University Press.

Hustak, A. (2013, July 18). Quebec writer Gaétan Soucy was preoccupied with alienation. The Globe and Mail. Retrieved September 9, 2016 from http://www.theglobeandmail.com/arts/books-andmedia/quebec-writer-gaetan-soucy-was-preoccupied-with-alienation/article13315610/

Kulperger, S. (2009). Familiar ghosts: Feminist postcolonial Gothic in Canada.” In C. Sugars \& G. Turcotte (Eds.), Unsettled remains: Canadian literature and postcolonial Gothic (pp. 97-124). Waterloo, ON: Wilfrid Laurier University Press.

Laouyene, A. (2009). Canadian Gothic and the work of ghosting in Ann-Marie MacDonald's Fall on Your Knees. In C. Sugars \& G. Turcotte (Eds.), Unsettled remains: Canadian literature and postcolonial Gothic (pp. 125-154). Waterloo, ON: Wilfrid Laurier University Press.

May, C. (2002). Childhood lost. Canadian Literature, 175(Winter), 148-150. Retrieved September 10, 2016 from https://canlit.ca/full-issue/?issue $=175$

Soucy, G. (2000). The little girl who was too fond of matches. Toronto, ON: Anansi. 
Sugars, C., \& Turcotte, G. (2009). Introduction: Canadian literature and the postcolonial Gothic. In C. Sugars \& G. Turcotte (Eds.), Unsettled remains: Canadian literature and postcolonial Gothic (pp. vii-xxvi). Waterloo, ON: Wilfrid Laurier University Press.

Whelan, J. (2011). Interpreting comparisons in La Petite Fille qui aimait trop les allumettes by Gaétan Soucy. In P.-A. Mevel \& H. Tattam (Eds.), Modern French identities: Language and its contexts (pp. 177-202). Frankfurt am Main, Germany: Peter Lang.

Wiesenthal, C. (2014). History's absent hand: Lessons in modes of (textual) production from Gaétan Soucy's The Little Girl Who Was Too Fond of Matches. Studies in Canadian Literature, 39(2). Retrieved September 10, 2016 from http://journals.lib.unb.ca/index.php/scl/article/view/23045/26739 